ISSN 0258-7122 (Print), 2408-8293 (Online)

Bangladesh J. Agril. Res. 41(3): 507-519, September 2016

\title{
EFFECT OF PRETREATMENTS AND PACKAGING ON THE GROWTH OF BACTERIA IN VALUE ADDED SUMMER ONION PRODUCTS
}

\author{
M. M. ALAM ${ }^{1}$ AND M. N. ISLAM ${ }^{2}$
}

\begin{abstract}
The experiment was carried out to investigate the bacteria in fresh and different processed onion. Total number of viable bacteria (cfu/g) in fresh onion and dehydrated processed onion packed in High Density Ployethylene (HDPE) and Aluminum foil (ALF) was estimated at 0,6 and 12 month interval following storage at room temperature $\left(\mathrm{RT}, 20-25^{\circ} \mathrm{C}\right)$ and refrigerated temperature (RFT, $\left.5^{0} \mathrm{C}\right)$. Samples tested were fresh onion $\left(\mathrm{S}_{0}\right)$, dried onion $\left(\mathrm{S}_{1}\right)$, blanched and dried $\left(\mathrm{S}_{2}\right)$, blanched + sulphited and dried $\left(\mathrm{S}_{3}\right), 25 \%$ salt osmosed and dried $\left(\mathrm{S}_{4}\right), 60 \%$ sugar osmosed and dried $\left(\mathrm{S}_{5}\right)$ and $55 / 15 \%$ sugar-salt osmosed dried onion $\left(\mathrm{S}_{6}\right)$. It was found that the lowest bacterial count $\left(2 \times 10^{1}\right.$ and $9 \times 10^{1}$ $\mathrm{cfu} / \mathrm{g}$ ) was given by $25 \%$ salt osmosed onion $\left(\mathrm{S}_{4}\right)$ and the total number of vialed bacteria (TVB) count in the other samples varied in the order of $S_{3}<S_{6}<$ $\mathrm{S}_{5}<\mathrm{S}_{2}<\mathrm{S}_{1}\left(45-97 \times 10^{3} \mathrm{cfu} / \mathrm{g}\right)$ and sample $\mathrm{S}_{1}$ having no pretreatment before drying gave the highest TVB among the samples and the preservation effect was only due to reduction of $\mathrm{a}_{\mathrm{w}}$ during drying.
\end{abstract}

Keywords: Pretreatments, packaging, bacteria, value added summer onion

\section{Introduction}

Onion is a herbal crop used as a spice in various food items principally in Indian Sub-continent and some other part of Asia. Onion is a bulb growing on the upper surface of the soil where the leaves of the onion become thick and watery starting from the stem and tapering to the top forming a bulb. Soil is the store house of all kinds of microorganisms and when soil adheres to the outer surface of the bulb the onion is contaminated. Water, air and handling may also contaminate onion. Microorganisms thus transferred in freshly harvested onion may find their way to processed product. The number and kind of spoilage microorganisms could be reduced by avoiding or removing contaminated outer leaves, by chemical preservative, heat treatment of onion, careful dehydration, sizing and milling the onions (Sheneman, 1973).

The aerobic mesophilic bacteria are important for measuring the microbiological quality of the fresh and processed product. Hence the growth of microorganisms in fresh and processed onions is important to develop high quality preserved onion especially from safety and hygienic view point (Sheneman, 1973).

${ }^{1}$ Senior Scientific Officer, Spices Research Center, Bangladesh Agricultural Research Institute (BARI), Shibgonj, Bogra. ${ }^{2}$ Professor, Department of Food Technology and Rural Industries, Bangladesh Agricultural University (BAU), Mymensingh, Bangladesh. 
Vaughn (1951) investigated the effect of various production factors on microbiological population of onions and other dehydrated vegetables. $\mathrm{He}$ showed that steam blanching of raw vegetables could reduce $99.9 \%$ of total plate count. Dehydrated unblanched onions had higher bacterial population, than those of all blanched vegetables. Vaughn (1951) also studied the incidence and significance of several groups of bacteria in dehydrated onion and garlic and observed that it was difficult to select a meaningful quantitative index for microbiological quality of dehydrated onion products.

A number of bacteria can grow in high concentrations of sugar or salt called osmophilic organisms. Some of them are able to grow at water activity as low as 0.60 (Frazier and Westhoff, 1978). Nunheimer and Fabian (1940) stated that the growth and activity of staphylococci are inhibited at $15 \%$ salt concentration and cannot survive at $20 \%$ salt concentration.

A study showed that 36 nonpathogenic bacteria did not grow over $16 \%$ salt and 31 pathogenic organisms did not grow at $10 \%$ salt solution. Among the yeast genus, Rhodotorula were found most resistant to salt. Clostridium botulinum, an anaerobic bacterium, was inhibited under certain conditions in 10 percent salt concentration (Weiser, 1967).

The sugar and its concentrations have been shown to determine its ability to accelerate or prevent the growth of micro-organisms. Usually sugar concentration from 1 to 10 percent will materially influence the growth of certain kinds of organisms, while a strength of $50 \%$ sugar stopped the growth of most bacteria and yeasts. Bacteria rarely survive in 20 to $25 \%$ sugar concentrations; usually 70 \%sugar stopped the growth of all micro-organisms (Weiser, 1967).

The incidence of microorganisms in vegetables may be expected to reflect the sanitary quality of the processing steps and the microbiological condition of the raw product at the time of processing. Splittstoesser et al. (1961) showed that the total counts ranged from $\log 5.60$ to over 6.00 in green beans before blanching in 2 production plants. After blanching, the total numbers were reduced to $\log 3.00$ $3.60 /$ g. After passing through the various processing stages and packaging, the counts (after packaging) ranged from $\log 4.72-5.94 / \mathrm{g}$.

Jay (1978) stated that blanching or scalding is a vital step prior to dehydration. This may be achieved by immersion in hot water at $100^{\circ} \mathrm{C}$ for $1-8 \mathrm{~min}$, depending upon the particular type of product. The primary function of this step is to destroy enzymes that may bring about undesirable changes in the finished products. Leafy vegetables generally require less time for blanching than peas, beans, or carrots. It has been shown that for many vegetables safe drying temperature ranges from $60-63^{\circ} \mathrm{C}$. The moisture content of vegetables could be reduced below $4 \%$ in order to satisfactory quality and storage. Vegetables may 
also be treated with $\mathrm{SO}_{2}$ or a sulfite for better product. The drying of vegetables is usually done using tunnel, belt, or cabinet driers.

Fanelli et al. (1965) found that reconstituted dehydrated onion soup contain a mean total bacterial count of $\log 5.11 / \mathrm{ml}$, with $\log 3.00$ coliforms, $\log 4.00$ aerobic sporeformers and $\log 1.08 / \mathrm{ml}$ of yeast and molds. On cooking the total counts were reduced to a mean of $\log 2.15$ while coliforms were reduced to less than $\log 0.26$, sproeformers to $\log 1.64$ and yeasts and molds to less than log $1.00 / \mathrm{ml}$.

McBean (1976) and Stafford et al. (1972) showed that sulfur dioxide preserves the texture, flavor, vitamins content and color of food. Sulphiting is widely used in the food industry to reduce fruit darkening during drying and storage. The sulfur dioxide from sulphiting displaces air from the tissue in plant materials, softens cell walls so that drying occurs more easily, destroys enzymes that cause darkening of cut surfaces, shows fungicidal and insecticidal properties, and enhances the bright attractive color of dried fruits. It also inhibits enzymatic and non enzymatic browning in dried fruit during storage and preserves ascorbic acid and carotene.

The overall objective of the research work was bacterial studies of fresh and dehydrated summer onion.

\section{Materials and Method}

Onion used in this study were washed and sliced into $5 \mathrm{~mm}$ thickness and initial moisture content was determined by oven drying method. Initial weight of each slice were taken. Some slices osmosed in $60 \%$ sucrose, $25 \%$ salt and 55/15\% sucrose-salt up to $24 \mathrm{hr}$ and weighted and subsequently individually marked by using different coloured threads. After the end of each definite time the slices were removed and quickly rinsed in water. Subsequently, surface water was removed by gently blotting with tissue-paper. The ratio of sugar to onion slices was $5: 1 \mathrm{w} / \mathrm{w}$.

The pieces which were used in this study were fresh onion, dried onion, blanching in hot water for $2 \mathrm{~min}$. and dried, blanching and sulphiting with 1500 ppm KMS and dried, immersed into $60 \%$ sucrose, $25 \%$ salt and $55 / 15 \%$ sucrosesalt solutions and dried.

The fresh and processed onion were packed in high density polyethylene (HDPE) and aluminium foil (ALF) and stored at room temperature (RT) and at refrigaration temperature (RFT). The stored dehydrated products (treated and untreated) were observed and analysed for growth and activity of bacteria at an interval of 6 months. 
The bacteria count was done in the laboratory of Seed Pathology Center and the department of Food Technology and Rural Industries, Bangladesh Agricultural University (BAU), Mymensingh.

\section{Determination of total viable Bacteria}

The total viable bacteria present in the fresh, dried and osmo-dehydrated onion were calculated following the standard plate count methods and technique as describe by Ranganna (1991) and Harrigan (1998).

\section{Preparation of agar media}

About $23.5 \mathrm{~g}$ of agar mix powder (containing, Casein-5 g, Yeast extract $2.5 \mathrm{~g}$, Dextrose $1.0 \mathrm{~g}$ and Agar $15.0 \mathrm{~g}$ ) was taken in a conical flask and $1000 \mathrm{ml}$ distilled water was added to it. It was heated to boiling for few minutes and then cooled to about $40^{\circ} \mathrm{C}$ temperature.

\section{Preparation of ringer solution}

About $2.15 \mathrm{~g}$ of sodium chloride, $0.075 \mathrm{~g}$ of potassium chloride, $0.12 \mathrm{~g}$ of calcium chloride and $0.5 \mathrm{~g}$ sodium thiosulphate were taken in a conical flask and mixed with $1000 \mathrm{ml}$ distilled water.

\section{Sample preparation}

The reliability of the analysis and interpretation of the results depend largely on the correct manner in which the sample was taken. The sample must be a true representative of the whole mass. For this purpose the product is thoroughly well mixed so that the sample would be the representative of the whole mass of the products. $10 \mathrm{~g}$ of well mixed onion were taken in $100 \mathrm{ml}$ volumetric flask and the volume was made up to $100 \mathrm{ml}$ with the ringer solution and mixed well by upand-down or to-and-fro movement.

At the same time to avoid contamination all the apparatus, solutions and other tools used were sterilized by heating in steam at $121^{\circ} \mathrm{C}$ under $15 \mathrm{psi}$ atmospheric pressure for 15 minutes. The prepared sample which already become diluted to 10 times was used as stock solution.

\section{Dilution}

A series of dilution were made as follows using $9 \mathrm{ml}$ blanks.

a) The initial $1 / 10$ dilution ( $10 \mathrm{~g}$ in $90 \mathrm{ml}$ ringer solution) was performed

b) This was mixed well in a vortex mixer. It becomes $10^{-1}$ time's dilution.

c) $1 \mathrm{ml}$ from (b) was taken and added to the next tube containing $9 \mathrm{ml}$ ringer solution and mixed well. It become $10^{-2}$ times dilution 
d) $1 \mathrm{ml}$ from (c) was taken and added to next tube containing $9 \mathrm{ml}$ ringer solution and mixed well. It then becomes $10^{-3}$ time's dilution.

In this way, the dilution was made up to $10^{-6}$ times. The scheme is shown in fig. 1

Stock Solution

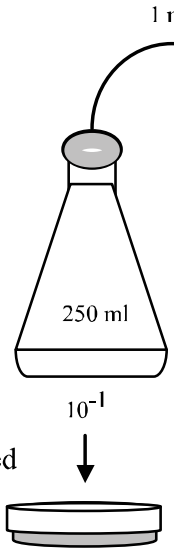

$10^{-1}$

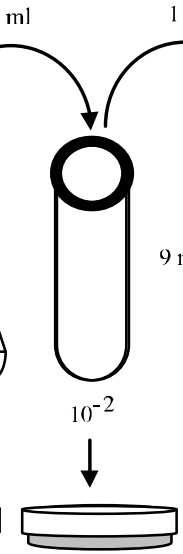

$10^{-2}$

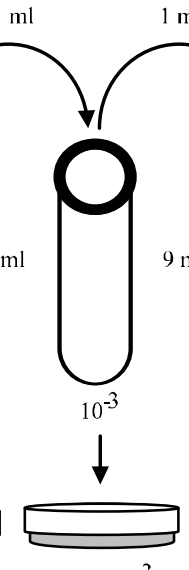

$10^{3}$

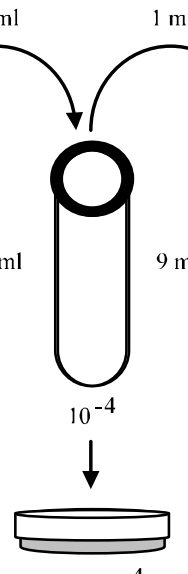

$10^{4}$
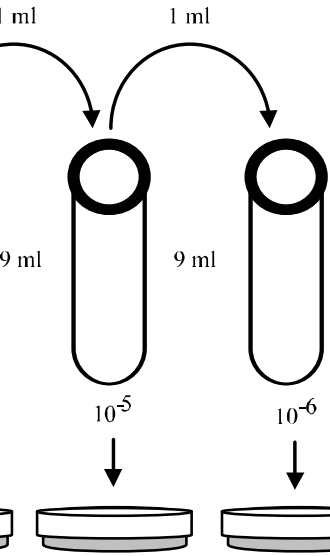

$10^{-5}$

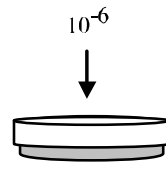

$10^{6}$

Fig.1 Simple serial dilution series using $9 \mathrm{ml}$ blanks and plating.

\section{Standard plate counts (SPC)}

Six sterilised petridishes were taken and each petridish was marked with each dilution number. About 15-20 ml nutrint agar media was taken in each petridish.1 $\mathrm{ml}$ of the diluted sample was then pipetted into each of these sterile petridishes. The contents of the plates were mixed well by swirling on a flat surface. Each dilution was plated in triplicate. After solidification of the media the plates were kept in incubator invertedly and incubated at $37^{\circ} \mathrm{C}$ for 24 to $72 \mathrm{hrs}$.

\section{Counting and recording}

After incubation for stipulated time the petridishes were taken out and checked. The plates containing segregated, overlapping and confusing colonies were avoided. The plates containing 30 to 250 bright, cleared and countable colonies were selected for easy counting of the colony.

Number of colony forming unit $(\mathrm{cfu}) / \mathrm{g}$ or $\mathrm{ml}=$ average $\mathrm{cfu} / \mathrm{plate} \times$ dilution factor

\section{Results and Discussion}

Total number of viable bacteria present in fresh onion and processed onion packed in HDPE and aluminum foil (ALF) was estimated at 0,6 and 12 month interval following storage at room temperature (RT, $20-25{ }^{\circ} \mathrm{C}$ ) and refrigerated temperature (RFT, $5^{\circ} \mathrm{C}$ ). The total number of viable bacteria (TVB) present per $\mathrm{g}$ of different types of dehydrated onion samples were calculated by multiplying 
the total number of colony forming units (cfu) on the plate with its dilution factor. The results for TVB are given in Table 1 and the results and discussion for bacterial growth are presented below.

From Table 1, it is seen that initial number of viable bacteria was highest $\left(9.5 \times 10^{4} \mathrm{TVB}\right)$ in fresh onion $\left(\mathrm{S}_{0}\right)$ compared to dried onion samples $\left(\mathrm{S}_{1}\right.$ to $\left.\mathrm{S}_{6}\right)$ and was successively followed by dried onion without pretreatment $\left(\mathrm{S}_{1}\right)$ with $4.5 \times 10^{4}$ TVB , only blanched and dried onion $\left(\mathrm{S}_{2}\right)$ with $7.5 \times 10^{3} \mathrm{TVB}, 60 \%$ sugar osmosed and dried onion $\left(\mathrm{S}_{5}\right)$ with $4.7 \times 10^{3} \mathrm{TVB}, 55 / 15 \%$ sugar-salt osmosed and dried $\left(\mathrm{S}_{6}\right)$ with $2.5 \times 10^{3} \mathrm{TVB}$, blanched, sulphited and dried onion $\left(\mathrm{S}_{3}\right)$ with $2.5 \times 10^{2} \mathrm{TVB}$, while the lowest bacterial count $\left(2 \times 10^{1} \mathrm{TVB}\right)$ was given by $25 \%$ salt osmosed and dried onion $\left(\mathrm{S}_{4}\right)$.

Table 1. Growth of bacteria in fresh and dried onion in different packaging materials during 12 month of storage at RT and RFT

\begin{tabular}{|c|c|c|c|c|c|c|c|c|c|}
\hline \multirow{4}{*}{$\begin{array}{c}\text { Types of } \\
\text { sample }\end{array}$} & \multirow{3}{*}{$\begin{array}{c}\text { Bacteria } \\
\text { count } \\
\text { on the day } \\
\text { of } \\
\text { preparation } \\
\text { of } \\
\text { dried onion }\end{array}$} & \multicolumn{4}{|c|}{$\begin{array}{l}\text { No of bacteria in Room } \\
\text { temperature (RT) }\end{array}$} & \multicolumn{4}{|c|}{$\begin{array}{l}\text { No of bacteria } \\
\text { Refrigeration temperature (RFT) }\end{array}$} \\
\hline & & \multicolumn{2}{|c|}{ Packed in HDPE } & \multicolumn{2}{|c|}{$\begin{array}{l}\text { Packed in } \\
\text { aluminum foil }\end{array}$} & \multicolumn{2}{|c|}{ Packed in HDPE } & \multicolumn{2}{|c|}{$\begin{array}{l}\text { Packed in } \\
\text { aluminum foil }\end{array}$} \\
\hline & & 6 month & 12 month & $\begin{array}{c}6 \\
\text { month }\end{array}$ & $\begin{array}{c}12 \\
\text { month }\end{array}$ & 6 month & 12 month & $\begin{array}{c}6 \\
\text { month }\end{array}$ & $\begin{array}{c}12 \\
\text { month }\end{array}$ \\
\hline & $\mathrm{cfu} / \mathrm{g}$ & $\mathrm{cfu} / \mathrm{g}$ & $\mathrm{cfu} / \mathrm{g}$ & $\mathrm{cfu} / \mathrm{g}$ & $\mathrm{cfu} / \mathrm{g}$ & $\mathrm{cfu} / \mathrm{g}$ & $\mathrm{cfu} / \mathrm{g}$ & $\mathrm{cfu} / \mathrm{g}$ & $\mathrm{cfu} / \mathrm{g}$ \\
\hline $\mathrm{S}_{0}$ & \multicolumn{9}{|l|}{$9.5 \times 10^{4}$} \\
\hline $\mathrm{S}_{1}$ & $4.5 \times 10^{4}$ & $7.8 \times 10^{4}$ & $9.7 \times 10^{4}$ & $4.6 \times 10^{4}$ & $4.6 \times 10^{4}$ & $5.0 \times 10^{4}$ & $5.2 \times 10^{4}$ & $4.5 \times 10^{4}$ & $4.5 \times 10^{4}$ \\
\hline $\mathrm{S}_{2}$ & $7.5 \times 10^{3}$ & $8.8 \times 10^{3}$ & $9.2 \times 10^{3}$ & $7.5 \times 10^{3}$ & $7.6 \times 10^{3}$ & $7.8 \times 10^{3}$ & $7.9 \times 10^{3}$ & $7.5 \times 10^{3}$ & $7.6 \times 10^{3}$ \\
\hline $\mathrm{S}_{3}$ & $2.5 \times 10^{2}$ & $5.5 \times 10^{2}$ & $6.7 \times 10^{2}$ & $2.7 \times 10^{2}$ & $2.7 \times 10^{2}$ & $3.0 \times 10^{2}$ & $3.2 \times 10^{2}$ & $2.6 \times 10^{2}$ & $2.6 \times 10^{2}$ \\
\hline $\mathrm{S}_{4}$ & $2 \times 10^{1}$ & $7 \times 10^{1}$ & $9 \times 10^{1}$ & $3 \times 10^{1}$ & $3 \times 10^{1}$ & $4 \times 10^{1}$ & $5 \times 10^{1}$ & $2 \times 10^{1}$ & $2 \times 10^{1}$ \\
\hline $\mathrm{S}_{5}$ & $4.7 \times 10^{3}$ & $6.5 \times 10^{3}$ & $8.5 \times 10^{3}$ & $4.9 \times 10^{3}$ & $4.8 \times 10^{3}$ & $5.4 \times 10^{3}$ & $5.8 \times 10^{3}$ & $4.7 \times 10^{3}$ & $4.7 \times 10^{3}$ \\
\hline $\mathrm{S}_{6}$ & $2.5 \times 10^{3}$ & $3.9 \times 10^{3}$ & $5.4 \times 10^{3}$ & $2.7 \times 10^{3}$ & $2.7 \times 10^{3}$ & $2.7 \times 10^{3}$ & $3.8 \times 10^{3}$ & $2.5 \times 10^{3}$ & $2.6 \times 10^{3}$ \\
\hline
\end{tabular}

So $=$ Fresh onion, $S_{1}=$ Dried onion, $S_{2}=$ Blanching in hot water for 2 min. and dried, $S_{3}=$ Blanching + Sulfiting with 1500ppm KMS and dried, $\mathrm{S}_{4}=$ Osmosed with $25 \%$ salt solution and dried, $\mathrm{S}_{5}=$ Osmosed with $60 \%$ sugar solution and dried, $\mathrm{S}_{6}=$ Osmosed with $55 / 15 \%$ Sugar- salt solution and dried.

From Table 1, it is found that upon 12 month storage in HDPE at RT the highest no. of bacteria was found in sample without pretreatment $S_{1}\left(9.7 \times 10^{4}\right)$ followed successively by $S_{2}\left(9.2 \times 10^{3}\right), S_{5}\left(8.5 \times 10^{3}\right), S_{6}\left(5.4 \times 10^{3}\right), S_{3}\left(6.7 \times 10^{2}\right)$ and the lowest number $\left(9 \times 10^{1}\right)$ was given by $S_{4}(25 \%$ salt osmosed and dried). On the other hand, the highest number of bacteria for the same duration in ALF at RT was found again in sample $S_{1}\left(4.6 \times 10^{4}\right)$ followed in descending order by $S_{2}$ $\left(7.6 \times 10^{3}\right), S_{5}\left(4.8 \times 10^{3}\right), S_{6}\left(2.7 \times 10^{3}\right), S_{3}\left(2.7 \times 10^{2}\right)$ and $S_{4}\left(3 \times 10^{1}\right)$. It is thus 
seen that number of viable bacteria/g (TVB) in all samples were lower in ALF compared to HDPE upon 12 month storage at RT. In case of RFT it was also seen that the highest number of bacteria in HDPE was found in sample $S_{1}$ $\left(5.2 \times 10^{4}\right)$ followed by $\mathrm{S}_{2}\left(7.9 \times 10^{3}\right), \mathrm{S}_{5}\left(5.8 \times 10^{3}\right), \mathrm{S}_{6}\left(3.8 \times 10^{3}\right), \mathrm{S}_{3}\left(3.2 \times 10^{2}\right)$ and $\mathrm{S}_{4}\left(5 \times 10^{1}\right)$. It is also seen that the above samples gave lower bacterial count up to 12 month in ALF compared to HDPE (both at RFT), as well as maintained similar sample order as noted for HDPE at RFT (i.e highest in $\mathrm{S}_{1}$ and the lowest in $S_{4}$ ) in respect of bacterial growth. The highest number was $45 \times 10^{3}$ in $S_{1}$ and the lowest number was $2 \times 10^{1}$ in $\mathrm{S}_{4}$. It is thus found that for a given sample in similar packaging material gave lower number of bacteria for a given storage period at RFT than at RT. While keeping other conditions (such as storage time and temperature) constant, any one of the samples gives lower bacterial count in ALF than in HDPE. Again, at a given identical packaging and temperature conditions, $25 \%$ salt osmosed product gave the lowest bacterial count among the samples for a given period. In general the initial bacterial count and that following storage were the highest in $\mathrm{S}_{0} / \mathrm{S}_{1}$ and was followed in descending order by $S_{2}, S_{5}, S_{6}, S_{3}$ and $S_{4}$ after a specific period at constant conditions such as temperature and packaging.

From Table 1, it is also seen that all processed samples in HDPE as well as ALF shows higher number of total bacteria count as storage time at RT as well as RFT increases. It was thus of interest to analyze dependence of bacterial growth on time to show whether it follows first order reaction kinetics. Data were analyzed as per Heldman (1977) and Villota and Hawkes (1992) and rate constants were calculated and shown in Table 2.

Table 2. Rate constant of growth of bacteria in different film and storage condition.

\begin{tabular}{c|c|c|c|c|c|c|c}
\hline Organism & $\begin{array}{c}\text { Storage } \\
\text { Condition }\end{array}$ & $\mathrm{S}_{1}$ & $\mathrm{~S}_{2}$ & $\mathrm{~S}_{3}$ & $\mathrm{~S}_{4}$ & $\mathrm{~S}_{5}$ & $\mathrm{~S}_{6}$ \\
\hline Bacteria & RT +HDPE & 0.768 & 0.204 & 0.986 & 1.504 & 0.592 & 0.770 \\
& RT+ALF & 0.022 & 0.013 & 0.077 & 0.405 & 0.062 & 0.077 \\
& RFT+HDPE & 0.145 & 0.052 & 0.247 & 0.916 & 0.210 & 0.419 \\
& RFT+ALF & - & 0.013 & 0.039 & - & - & 0.039 \\
\hline
\end{tabular}

$\mathrm{S}_{1}=$ Dried onion, $\mathrm{S}_{2}=$ Blanching in hot water for $2 \mathrm{~min}$. and dried, $\mathrm{S}_{3}=$ Blanching + Sulfiting with 1500ppm KMS and dried, $\mathrm{S}_{4}=$ Osmosed with $25 \%$ salt solution and dried, $\mathrm{S}_{5}=$ Osmosed with $60 \%$ sugar solution and dried, $\mathrm{S}_{6}=$ Osmosed with 55/15\% Sugar- salt solution and dried.

From Table 2 it is seen that amongst the samples the highest rate constant $(\mathrm{K})$ was found in $\mathrm{S}_{4}$, at any constant storage condition such as: RT +HDPE, $\mathrm{RT}+\mathrm{ALF}$ etc. and varied from $0-1.504^{-\mathrm{yr}}$. Rate constants were very low and in some cases even zero for RFT+ALF. For a given sample at RT or RFT, K value 
is much higher for a given product packed in HDPE than in ALF. Again for any one of the samples packed either in HDPE or in foil, $\mathrm{K}$ value is quite higher at RT compared to RFT. Rate constant values suggest that TVB count and position shown earlier may be shifted after storage period longer than one year.

The observation that the lowest bacterial count is given by $25 \%$ salt osmosed onion and the TVB count in the other samples varied in ascending order such as $\mathrm{S}_{3}, \mathrm{~S}_{6}, \mathrm{~S}_{5}, \mathrm{~S}_{2}$ and $\mathrm{S}_{1}$ may be attributed to the differences of the effect of pretreatment prior to drying (with resultant $\mathrm{a}_{\mathrm{w}}$ depression) such as infusion of salt during osmosis $\left(\mathrm{S}_{4}\right)$, presence of sulpher + heat inactivation (in $\mathrm{S}_{3}$ ), infusion of salt-sugar following osmosis $\left(\mathrm{S}_{6}\right)$, infused sucrose $\left(\mathrm{S}_{5}\right)$, blanching or heat inactivation $\left(S_{2}\right)$ and sample receiving no pretreatment $\left(S_{1}\right)$ before drying gave the highest TVB among the samples and the preservation effect in this case $\left(\mathrm{S}_{1}\right)$ is only due to reduction of $\mathrm{a}_{\mathrm{w}}$ during drying.

Sodium chloride when infused in food system reduces water activity when compared to original food with similar moisture content. Additionally microorganisms are sensitive to the toxicity of $\mathrm{NaCl}$ (Nickerson and Sinsky, 1997). Sodium actually combines with protoplasmic anions of the cell and thus exerts a toxic effect upon the organisms (Winslow and Falk, 1923). Another concept is the toxicity of the $\mathrm{Cl}$ ion. Kadam et al. (2009) found almost similar result (bacteria $18.33 \mathrm{cfu} / \mathrm{g}$ ) after 5 month of storage of dried onion, when onions were treated with KMS and sodium chloride. Salt has a marked effect in suppressing the growth of many undesirable organisms in food products. The micro-organisms may grow but their enzyme systems may be altered in such a way that no noticeable change takes place in the food. $\mathrm{NaCl}$ has a very fixed lethal action in the presence of heat (as in drying) against many kinds of micro cocci. It is observed that likewise, alkaline solutions of salt tend to reduce the thermal death times of spores. Several investigators opined that $\mathrm{NaCl}$ in concentrations used in food preservation is not a bactericide but serves as a bacteriostatic agent against most varieties of microorganisms. As reported by Weiser, (1967), the U.S Department of Agriculture (USDA), however stated that 18$25 \%$ brine solution would prevent microbial growth.

The observed highest rate constant (1.5/yr) given by $25 \%$ salt osmosed onion $\left(\mathrm{S}_{4}\right)$ in RT+HDPE may be due to low initial bacterial count resulting in lower level of competition as well as dilution of salt following water uptake during storage. However due to initial lowest TVB after $1 \mathrm{yr}$. of storage TVB is still the lowest and negligible $\left(2 \times 10^{1}-9 \times 10^{1} \mathrm{TVB} / \mathrm{g}\right)$.

Sulfur dioxide or salts of sulfur are used in foods in order to prevent enzymatic and non enzymatic browning but these are also used in numerous instances to prevent the growth of undesirable microorganisms (Arsdel et al., 1973, Nickerson and Sinskey, 1977). The preservative action of $\mathrm{SO}_{2}$ has been attributed 
to its reaction with the carbonyls of carbohydrates, thus preventing their utilization as a source of energy, or the reduction of S-S linkages in enzyme proteins, thus preventing enzyme activities (Josyln and Braverman, 1954). Rehm (1964) showed that nicotine amide adenine dinucleotide (NAD)-dependent factors concerned with the metabolism of certain carbohydrates by some yeast and bacteria are inhibited by sulfurous acid, probably due to the formation of additional compounds between the two components. While discussing preservative action of sulfurdioxide, Rahman (1999) mentioned that sulphiting is widely used in the food industry to reduce fruit darkening during drying and storage. The sulfur dioxide from sulphiting displaces air from the tissue in plant materials, softens cell walls so that drying occurs more easily, destroys enzymes that cause darkening of cut surfaces, shows fungicidal and insecticidal properties, and enhances the bright attractive color of dried fruits. McBean (1976) also reported that $\mathrm{SO}_{2}$ inhibits enzymatic and non enzymatic browning in dried fruit during storage and preserves ascorbic acid and carotene.

However, a disadvantage of sulphite is that it may be detected by some people at very low concentration in the reconstituted product and consider the taste objectionable (Arsdel et al., 1973).

Blanching inactivates enzymes, reduces of microorganisms and displaces entrapped air in the plant tissues. It has been claimed by Jay (1978) that initial microbial loads as high as $99 \%$ will be reduced by blanching. Similar effect of blanching on microbial load has been indicated by Arsdel et al (1973). Fuselli et al. (2004) showed that the use of additional barriers such as blanching or brine immersion produces an important effect on the microbiological stability in garlic and onion products. Thus combined effect of blanching and sulphiting was more pronounced as in $S_{3}$ (with $6.7 \times 10^{2} \mathrm{TVB}$ ) compared to $\mathrm{S}_{2}$ (with $9.2 \times 10^{3} \mathrm{TVB}$ ) securing after 12 month in HDPE at RT (the worst condition).

Lower number of bacteria in $S_{5}$ and $S_{6}$ compared to both $S_{1}$ and $S_{2}$ may be attributed to infused sugar and sugar-salt respectively during osmosis. Salt and sugar act very much in the same way upon microorganisms. If the salt and sugar concentration are sufficiently high it acts as preservative by increasing the osmotic pressure. The moisture content of the food is withdrawn and the tissues are plasmolyzed thus there is insufficient moisture for the growth of microorganisms. Erickson and Fabian (1942) investigated the germicidal action of various sugars and reported that addition of sugar and salt could reduce the water activity $\left(\mathrm{a}_{\mathrm{w}}\right)$ of a food. 

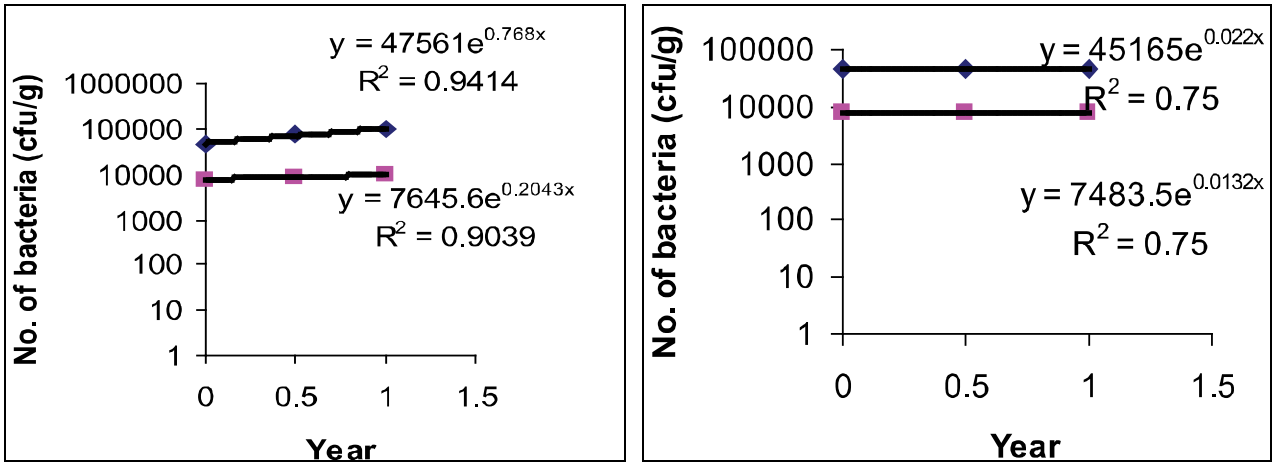

Fig. 1. TVB in HDPE at 0,6 and 12 month for RT for $S_{1} \& S_{2}$.

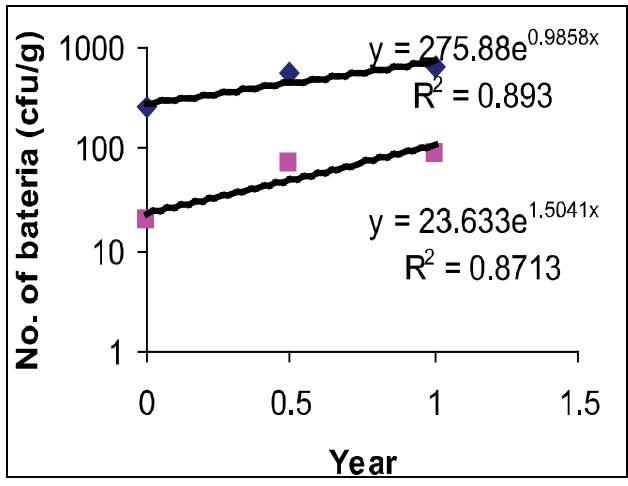
month for RT for $S_{1} \& S_{2}$

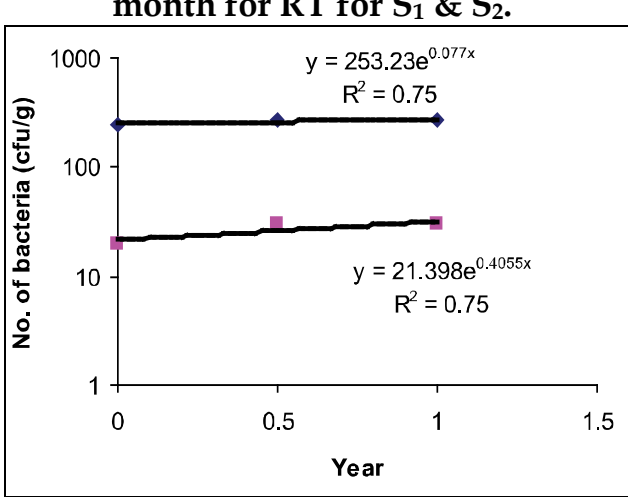

Fig. 2. TVB in HDPE at 0,6 and 12 month for RT for $S_{3} \& S_{4}$.

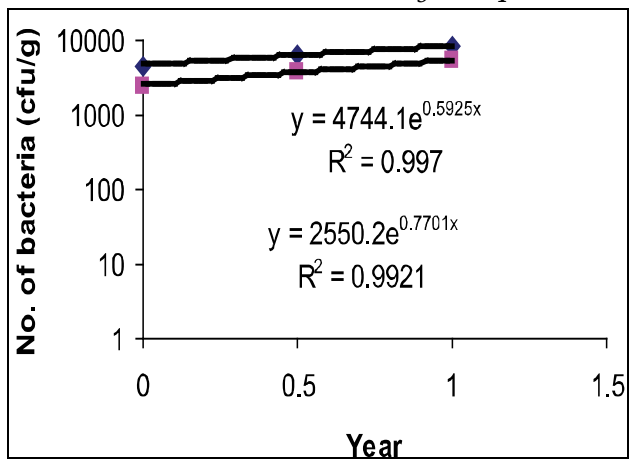

Fig. 5. TVB in ALF at 0,6 and 12 month for RT for $S_{3} \& S_{4}$.

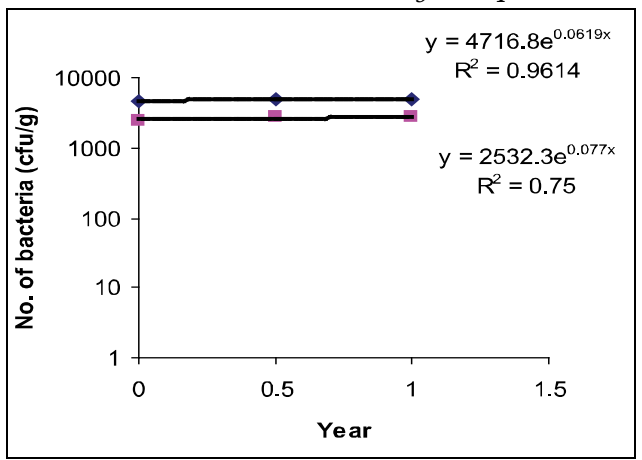

Fig. 3. TVB in HDPE at 0,6 and 12 Fig. 6. TVB in ALF at 0,6 and 12 month for RT for $S_{5} \& S_{6}$. month for RT for $S_{5} \& S_{6}$. 

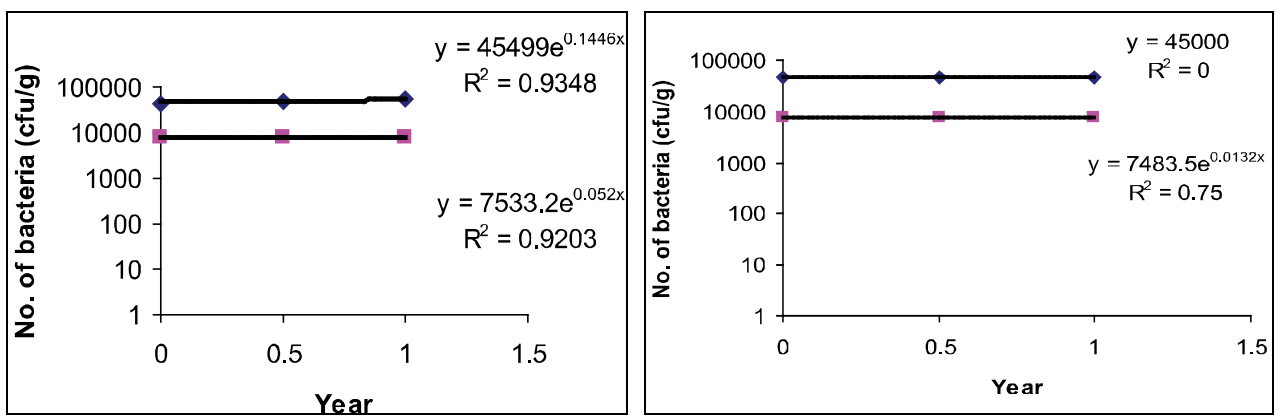

Fig. 7. TVB in HDPE at 0,6 and 12 month for RFT for $S_{1} \& S_{2}$.

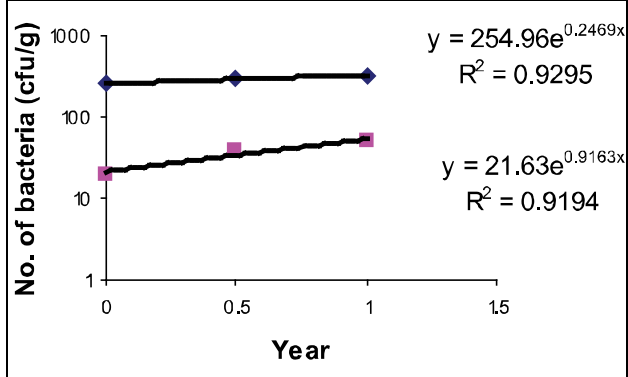

Fig. 10. TVB in ALF at 0,6 and 12 month for RFT for $S_{1} \& S_{2}$.

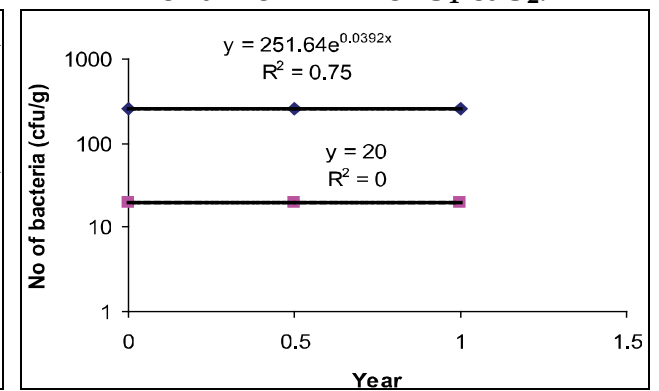

Fig. 8. TVB in HDPE at 0,6 and 12 Fig. 11. TVB in ALF at 0, 6 and 12 month for RFT for $\mathrm{S}_{3} \& \mathrm{~S}_{4}$.

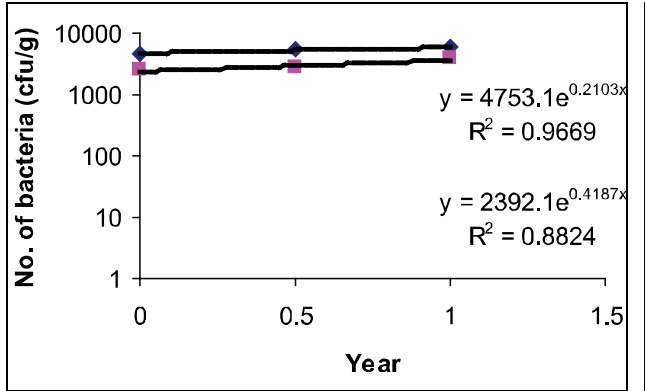
month for RFT for $S_{3} \& S_{4}$.

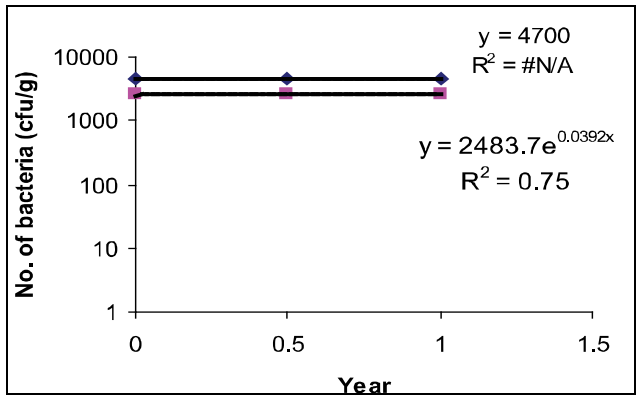

Fig. 9. TVB in HDPE at 0,6 and 12 Fig. 12. TVB in ALF at 0, 6 and 12 month for RFT for $S_{5} \& S_{6}$. month for RFT for $S_{5} \& S_{6}$.

The observed lower TVB in $\mathrm{S}_{6}\left(2.7 \times 10^{3}\right)$ and $\mathrm{S}_{5}\left(4.8 \times 10^{3}\right)$ compared to $\mathrm{S}_{1}$ (4.6x $\left.10^{4} \mathrm{TVB}\right)$ and $\mathrm{S}_{2}\left(7.6 \times 10^{3}\right)$ in ALF at RT (12 month) may be attributed to infusion of salt and sugar respectively. Salt is more effective chemical to inhibit bacteria by $\mathrm{a}_{\mathrm{w}}$ depression and toxicity, where as sugar is not that effective. The results are in agreement with the finding of Jay (1978) who stated that sugars, such as sucrose, exerted their preserving effect in essentially the same manner as salt, but it generally requires about 6 times sucrose than $\mathrm{NaCl}$ to effect the same degree of inhibition. It should be pointed out that the bacterial count in dehydrated sample without pretreatment $\left(S_{1}\right)$ is also not that high particularly 
after 12 months in ALF at RT $\left(46 \times 10^{3}\right.$ TVB) due to low moisture content (following drying) and resultant $\mathrm{a}_{\mathrm{w}}(0.2)$ and the product is shelf-stable (Islam and Flink, 1982 b, Nickerson and Sinskey 1977).

Higher rate constant as well as TVB for samples in HDPE compared to ALF at both RT and RFT storage is due to more water migration through HDPE than ALF. Comparatively higher moisture uptake by HDPE than ALF with resultant increased $\mathrm{a}_{\mathrm{w}}$, depends on permeability, thickness and temperature.

The observation that the bacterial load of all treated sample in RFT storage either packed in HDPE or ALF showed comparatively lower bacterial count as well as lower rate constant (Table 1 and Table 2) than those stored at RT is due to the fact that bacterial activity is lower at low temperature such as $5^{\circ} \mathrm{C}$ compared to room temperature $\left(20-25^{\circ} \mathrm{C}\right)$. In fact rate constant of bacterial growth has an Arrhenius type relationship with absolute temperature (Heldman, 1977, Villota and Hawkes, 1992).

\section{Conclusion}

For long time storage Alaminius Forl (ALF) may be used at Room Temperature (RT). The pretreated samples particularly $25 \%$ salt osmosed + dried onion, 55/15 $\%$ sugar/salt osmosed dried, blanched sulphited dried onion, blanched dried are recommended for drying and storage from microbial stability point of view, cost of osmosis solution etc.

\section{References}

Arsdel, V., M.J. Copley and A.I. Morgan. 1973. Food dehydration. Volume I. AVI publishing company, Inc., Westport, Conn., USA.

Erickson, F.J.and F.W. Fabian. 1942. Preserving the germicidal action of various sugars and organic acids on yeasts and bacteria. Food research. 7 : 68-79.

Fanelli, M.J., A.C. Peterson and M.F. Gunderson. 1965A. Microbiology of dehydrated soups.I. A survey. Food Technol. 19: 83-86.

Frazier, W.C. and D.C. Westhoff . 1978. In : Food Microbiology. $3^{\text {rd }}$ edition, McGrawHill, NewYork.

Fuselli, S.R. B Filsinger and R. Fritz. 2004. Microbiological study of garlic and onion. Revista-Argentina-de-Microbiologia. 36(3) : 139-144.

Harrigan, W.F. 1998. Laboratory methods in Food microbiology, $3^{\text {rd }}$ edition, Academic press, San Diego, California 92101-4495, USA.

Heldman, D.R. 1977. Food Process Engineering. The AVI pub. Co. Reprint edition. West port, USA. Pp.237-311.

Islam, M.N. and J.M. Flink. 1982 . I. Dehydration of potato. I. Air and solar drying at low air velocities. J. Food Tech. 17: 373-385. 
Josyln, M.A. and J.B.S. Braverman. 1954. The chemistry and technology of the pretreatment of fruit and vegetable products with sulfur dioxide and sulfites. Advance. Food Res. 5 : 97.

Jay, J.M. 1978. Modern Food Microbiology, New York. N.Y.10001.

Kadam, D.M., D.D. Nangare and H.S. Oberoi. 2009. Influence of pre-treatments on microbial load of stored dehydrated onion slices. Int. J. Food Sci. Tech. 44(10):1902-1908.

McBean, D. M. 1976. Drying and processing tree fruits, Division of Food Research Circular No.10, Commonwealth Scientific and Industrial Research Organisation, NSW, Australia.

Nickerson, J.T. and A.J. Sinskey. 1977. Microbiology of Foods and Food Processing, Elsevier North-Holland, Inc, New York.

Nunheimer, T.D. and F. W. Fabian. 1940. Influence of organic acid, sugars and sodium chloride upon strains of food processing staphylococci. Am. J. public Health. 30:1040-1049.

Rahman, M.S. and T.P. Labuza. 1999. Water activity and food preservation. In : Handbook of Food Preservation. Rahman MS (ed), Marcel Dekker Inc. New York. Pp. 339-382.

Ranganna, S. 1991. Manual of Analysis of fruit and vegetable products. Tata McgrawHill Publishing Co. Ltd. New Delhi, India.

Rehm, H.J. 1964. The antimicrobial action of sulfurous acid, " Microbial Inhibitors in Food", Almquist and Wiksell, Stockholm, Sweden. Pp. 105-115.

Sheneman, J.M. 1973. Survey of aerobic mesophilic bacteria in dehydrated onion products. J. Food Science. 38 :206.

Splittstoesser, D.F., W.P. Wettergreen and C.S.Pederson. 1961. Contol of microorganisms during preparation of vegetables for freezing. Green beans. Food Technol. 15. Pp. 329-331.

Stafford, A.E., H.R. Bolin and B.E. Mackey. 1972. Absorption of aqueous bisulphate by apricots. J. Food Sci. 37: 941.

Vaughn, R.H. 1951. The microbiology of dehydrated vegetables, Food res., 16: 429.

Villota and Hawkes. 1992. Kinetics in Food System . Book: Handbook of Food Engg. Edited by Heldmen, D.R. Pp. 57.

Weiser, H.H. 1967. Practical Food Microbiology and Technology, The AVI Publishing publishing Co., INC. England.

Winslow, C.E.A. and I.S. Falk. 1923. Studies on salt action. J. Bacteriol. 8: 215-236. 